\title{
Alicja Bieńkowska
}

\section{Działalność parlamentarna Juliusza Poniatowskiego w latach 1919-1927}

Zygmunt Hernmerling $w$ jednej ze swoich prac stwierdził, iż „Partie chłopskie lączyły i uogólniały dążenia jednostek, transformowały je, w oparciu o nie formowały programy polityczne i dążyly do wprowadzenia ich w życie. Jedną z głów-

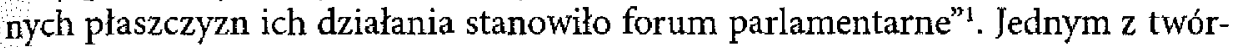
ców i głównych działaczy PSL „Wyzwolenie”, którego poglądy stanowity oparcie dla programu tejże partii, był Juliusz Poniatowski. Niniejszy artykuł stanowi zarys parlamentarnej działalności polityka od uzyskania mandatu poselskiego $\mathrm{W} 1919$ do 1927 roku, gdy zrezygnowal $z$ działalności poselskiej i odsunął się na kilka lat od życia parlamentarnego. W ramach aktywności poselskiej Poniatowskiego przedstawione zostaną poglądy, którymi się kierowal, główne projekty ustaw przez niego wspóltworzone oraz działania podejmowane przez Poniatowskiego wynikające $z$ pelnionej przez niego funkcji wicemarszałka. Rozprawa ta stanowi jednocześnie próbę odpowiedzi, na ile poglądy Poniatowskiego współtworzyły program PSL "Wyzwolenie", w jakim stopniu był on posłem aktywnym oraz czy był skutecznym politykiem.

Program realizowany w parlamencie przez PSL ,Wyzwolenie" powstawał na zjazdach partii i jej prezydium w czasie pierwszej wojny światowej, plasując ugrupowanie wśród lewicy parlamentarnej. Członkowie partii podkreślali, iż powstająca Polska powinna być państwem demokracji ludowej. Postulat ten starano się realizować droga reform parlamentarnych, choć nie wszyscy działacze uznawali tę drogę za skuteczną. Stanisław Thugutt w swojej autobiografii opisywał panujące nastroje na Walnym Zjeździe PSL 1-2 kwietnia 1918 r.: „Ton od początku był ostry. Pomimo względnie spokojnych referatów Poniatowskiego i mojego, sala drżała $z$ pasji $z$ trudem hamowanej. O rządzie wspólnym $z$ endekami nie chciano nawet słyszeć. Po przerwie południowej pierwszego dnia wróciwszy na salę zastałem Kurczaka nawołującego do natychmiastowego wyjścia na ulice i zaatakowania Niemców [...]"'. W zjeździe wzięło udział około 1000 członków Stronnictwa,

' Z. Hemmerling, PSL „Wyzwolenie" w parlamentach II Rzeczypospolitej 1919-1931, Warszawa 1990, s. 79.

${ }^{2}$ S. Thugutt, Autobiografia, Warszawa 1984, s. 107. 
w tym było 600 delegatów wybranych w myśl uchwalonego nowego statutu. Obecni byli czołowi przedstawiciele „Wyzwolenia”, którzy wygłaszali referaty o sytuacji politycznej (S. Thugutt), o zadaniach Sejmu (Stanislaw Osiecki), o ordynacji wyborczej (Aleksander Bogusławski), o kampanii wyborczej (Kazimierz Bagiński), o kwestiach samorządowych (Wojciech Januszewski). Poniatowski przedstawił zebranym swe poglądy na sprawy rolne $e^{3}$.

W kwestiach agrarnych program głosił konieczność przekazania ziemi w ręce ludu. Reformę rolną miało przeprowadzić państwo $z$ pomocą $w$ tym celu powolanego Urzędu Kolonizacyjnego, na rzecz którego miała być wywłaszczona wielka i średnia własność rolna przy opłacie za ziemię ustalonej według ceny urzędowej. Państwo ze zgromadzonych ziem miało tworzyć nowe gospodarstwa nie przekraczające 20 morgów (ok. 10 ha), powiększać małe, już istniejące gospodarstwa, tworzyć gospodarstwa spółdzielcze lub odsprzedawać chłopom ziemię za gotówkę, tworząc tą drogą gospodarstwa do 40 morgów. Większość działaczy PSL "Wyzwolenie" postulowała premiowanie gospodarstw bardzo drobnych, jednak Poniatowski przychylał się raczej ku wyznaczeniu minimalnej granicy posiadania na 40 morgów ${ }^{4}$.

PSL „Wyzwolenie" zakładało, iż przeprowadzenie reformy rolnej będzie latwiejsze przyjednoizbowym parlamencie. Dążyło także do przejęcia na własność państwa kolei, komunikacji wodnej, kopalń i fabryk. Na polu oświaty stawiano postulaty stworzenia jednolitej szkoły powszechnej, bezplatnej nauki dla najzdolniejszych dzieci, wyrównania poziomu nauczania w miastach i na wsiach, likwidacji analfabetyzmu oraz poprawy warunków materialnych nauczycieli. W pewnym stopniu przejawiający się w niektórych punktach programu radykalizm wynikał właśnie z tego, iż zaplecze społeczne partii stanowiła biedota, domagająca się glębokich zmian społecznych. Pod koniec 1918 r. „Wyzwolenie" skupia* to około 18000 członków, wśród których większość stanowili chłopi 5 .

Już pod koniec zjazdu PSL 2 listopada 1918 r. Poniatowski poinformowal poufnie Bogusławskiego, że Komisja Porozumiewawcza stronnictw lewicy niepodległościowej postanowiła powołać rząd w Lublinie. Poniatowski otrzymał w nim tekę ministra rolnictwa. W ogloszonym w nocy 6/7 listopada manifeście Tymczasowy Rząd Ludowy Republiki Polskiej stawiał postulaty zbliżone do głoszonych wcześniej przez PSL „Wyzwolenie": zwolanie Sejmu w oparciu o demokratyczną ordynację wyborczą, wprowadzenie ośmiogodzinnego dnia pracy, powszechne szkolnictwo oraz prawne zrównanie wszystkich obywateli. W ramach rolnictwa przewidywano upaństwowienie donaçji i majoratów, przymusowe wywłaszczenie i zniesienie wielkiej i średniej własności ziemskiej oraz oddanie jej w ręce chłopów,

${ }^{3}$ Archiwum Zakładu Historii Ruchu Ludowego (dalej: AZHRL), A. Bogusławski, Wspomnienia, T. II (1916-1919), sygn. P-31, s. 196-199.

${ }^{4}$ J. Jachymek, Myśl polityczna PSL „Wyzwolenie" 1918-1931, Lublin 1983, s. 58; Z. Hemmerling, op.cit., s. 30.

${ }^{5}$ Z. Hemmerling, op.cit., s. 71.

${ }^{6}$ AZHRL, A. Bogusławski, op.cit., s. 198. 
jednak bez ogłaszania dokładnych zasad przyszłej parcelacji. Rząd w Lublinie nie zdołał zdobyć szerszego poparcia społecznego. Formalnie istniał do 18 listopada, ale faktycznie jego władza skończyła się juź 11 listopada, gdy Józef Piłsudski wrócil do ojczyzny. Poniatowski, podobnie jak jego ugrupowanie, w pełni poparł oddanie pełni władzy w ręce Komendanta?

W czerwcu 1920 r. PSL „Wyzwolenie" zorganizowało kolejny zjazd partii, w którym wiodącymi tematami były konstytucja, reforma rolna, polityka rządu oraz sytuacja na froncie. W obliczu zbliżania się Armii Czerwonej do Warszawy szczególnie aktualna stawała się ostatnia kwestia, w związku z czym 24 lipca 1920 r. powstał Rząd Obrony Narodowej na czele $z$ Wincentym Witosem. Gabinet, powołany głównie w celu zachęcenia chłopów do walki na froncie, mial charakter koalicyjny, PSL "Wyzwolenie" reprezentowali w nim Poniatowski i Kazimierz Bartel"

W takich nielatwych warunkach rozpoczęly się obrady pierwszego Sejmu II Rzeczypospolitej. Przed jego powstaniem PSL "Wyzwolenie” opowiadało się za jednoizbowym parlamentem uważając, iż Senat ograniczy wpływ ludu na rządy i będzie utrudniał przeprowadzenie reformy rolnej. Podkreślano hasło reformy rolnej, lansowano również zjednoczenie ruchu ludowego $z$ trzech zaborów. Jednak pomimo faktu, iż połączenie partii ludowych postulowali również przedstawiciele wsi $z$ innych zaborów, ugrupowania nie zdołaly dojść do porozumienia, wobec czego PSL „Wyzwolenie” wystawiło własną listę kandydatów.

W partii obawiano się, iź wobec braku politycznego doświadczenia wsi wplywy wśród chłopów mogą zdobyć konkurencyjne ugrupowania ludowe, partie narodowe lub konserwatywne. W związku z tym, chcąc zwiększyć zaufanie chłopów do reprezentowanego przez siebie ugrupowania, PSL "Wyzwolenie" organizowało wiece, spotkania oraz kursy dla działaczy stronnictwa. Na kursach wykładowcami byli członkowie Zarządu Głównego PSL, m.in. Poniatowski, obecny w grudniu 1918 r. w Lublinie i w styczniu 1919 r. w Warszawie?.

Poniatowski miał optymistyczne przewidywania względem wyborów. Spodziewał się - podobnie jak K. Bagiński i Irena Kosmowska - iż partia otrzyma ponad sto mandatów na 296 miejsc w Sejmie. Lącznie w wyborach 26 stycznia 1919 r. „Wyzwolenie” wystawilo listy w 24 okręgach. By zwiększyć swe szanse na poparcie wśród chłopskiego elektoratu, ugrupowanie zdecydowało się umieszczać na pierwszych miejscach list wyborczych włościan $z$ danego okręgu, natomiast czołowi działacze partii startowali $z$ odleglejszych pozycji. $Z$ tego powodu Poniatowski wystawiony byl w okręgu konińskim $z$ numerem drugim.

PSL „Wyzwolenie" nie otrzymało tak szerokiego poparcia, jak zakładał Poniatowski, jednak oddało nań swe głosy $22 \%$ wyborców, co zapewniło partii 57 mandatów i status jednego z najliczniejszych chłopskich klubów poselskich. Grupa inteligencji wybranej do parlamentu $z$ list "Wyzwolenia" stanowiła zaledwie 26\% Klubu Poselskiego PSL „Wyzwolenie”, jednak odznaczała się znacznie więk-

\footnotetext{
'J. Borkowski, Ludowcy w II Rzeczypospolitej, cz. 1, Warszawa 1987, s. 30.

${ }^{8}$ Ibidem, s. 52.
}

${ }^{s}$ Z. Hemmerling, op.cit, s. $74-77$. 
szą aktywnością, niż posłowie chłopskiego pochodzenia, w związku z czym miała decydujący wplyw na jego działalnośćl ${ }^{10}$. W pracach brali udział również czołowi działacze partii, którzy odpadli w wyborach. Miejsca w parlamencie nie zdobyl m.in. S. Thugutt, zaś Poniatowski otrzymał mandat dopiero 2 kwietnia, gdy pod wpływem nacisków Władysław Kubus zrzekł się miejsca w Sejmie (wcześniej Po. niatowski starał się jeszcze zdobyć mandat w wyborach z okręgu Biała Podlaska 9 marca 1919 r., jednak bez rezultatów ${ }^{11}$. Nie wszystkim posłom odpowiadało, iż członkowie partii, którzy nie uzyskali mandatu, brali udział w pracach klubu sejmowego, czemu w swych pamiętnikach dał wyraz Maciej Rataj: „Odszukałem redakcję Wyzwolenia na Hortensji, gdzie zastałem menerów, którzy przy wybo. rach przepadli: Poniatowski, Radlińska, Margol [...], Róg, Wakar - same wyzwoleniowe tuzy. Uderzył mnie protekcjonalny ton w stosunku do posłów i bardzo widoczna chęć kierowania nimi zza kulis przez ściślejszą organizację, mafię, jak się później przekonałem, POW-iacką"i2.

W początkowym okresie przedstawiciele „Wyzwolenia" najczęściej zabierali głos w sprawach reformy rolnej, konstytucji i w kwestiach oświatowych. Zanim jakaś sprawa trafiala na forum Sejmu, najpierw dyskutowano na jej temat $w$ ramach Klubu oraz wybierano przedstawiciela, który zaprezentuje ją na posiedzeniu plenarnym $^{13}$. Poniatowski niejednokrotnie pisał przemówienia dla swoich kolegów, którzy później uczyli się ich „na pamięć," bowiem regulamin sejmowy zabraniał odczytywania przemówień. Zdarzyło się, iż gdy posel-chłop powtarzał w pokoju hotelowym wystąpienie przygotowane przez Poniatowskiego, przez ścianę słyszal je parlamentarzysta z innego ugrupowania i także się go nauczył. Następnego dnia poprosił o głos i sparodiował przemówienie, które chwilę później miał wygłosić poseł $z_{n}$ Wyzwolenia". Poniatowski spoliczkowal prześmiewcę, gdy ten zszedł $z$ mównicy ${ }^{14}$. $O$ ile jednak dziś byłoby to źle przyjęte, w okresie międzywojennym taka postawa uchodziła za przejaw honoru.

Hemmerling obliczył, iż $w$ dyskusjach związanych $z$ kwestiami rolnymi posłowie PSL „Wyzwolenie” przemawiali 54 razy, 26 przemówień poświęcili zagadnieniom konstytucyjnym, 18 razy byli referentami sprawozdań komisji, oprócz tego wielokrotnie zabierali głos w kwestiach formalnych. Klub PSL "Wyzwolenie" zgłosił około 170 interpelacji i wnioskówis.

Poniatowski został członkiem trzech ważnych dla partii komisji sejmowych: Konstytucyjnej, Likwidacyjnej i Rolnej, oprócz tego wielokrotnie zabierał głos w czasie obrad plenarnych. Na forum Sejmu, bez uwzględniania prac komisji,

I0 Ibidem, s. 80 .

1 AZHRL, A. Boguslawski, op.cit., s. 14; S. Giza, Kalendarz wydarzen historit ruchu ludowego (1895-1965), Warszawa 1967, s. 611.

12 M. Rataj, op.cit., s. 36.

${ }^{13}$ Z. Hemmerling, op.cit., s. 81 .

14 Relacja prof. Jana Góreckiego wygłoszona w trakcie spotkania „Juliusz Poniatowski w 120-lecie urodzin", zorganizowanego przez Wszechnice Obywatelską w Centralnej Bibliotece Rolniczej w Warszawie 24 i 2006 r. (notatki ze spotkania sporządzone przez autorkę artykulu).

${ }^{15}$ Z. Hemmering, op.cit., s. 81-82. 
wystąpil 92 razy, przez co był jednym z najaktywniejszych przedstawicieli PSL Wyzwolenie" oraz jednym $z$ aktywniejszych posłów w tej kadencji Sejmu (dla porównania prezes Zarządu Głównego PSL Błażej Stolarski zabierał głos 18 razy). Pierwszym oficjalnym działaniem Poniatowskiego na posiedzeniu plenarnym sejmu było złożenie w imieniu Klubu 2 maja 1919 r. wniosku w sprawie zniesienia granicy celnej z Księstwem Poznańskim. Poseł zrzekł się prawa głosu, ale uchwalono nagłość wniosku, który odesłano do Komisji Skarbowo - Budżetowej ${ }^{16}$.

Pierwsze przemówienie wygłosił Poniatowski kilka dni później, 9 maja $1919 \mathrm{r}$., na temat projektu konstytucji złożonego w Sejmie przez Klub PSL „Wyzwolenie”"17. Rozpoczął od ostrzeżenia, ,żeby po wyjściu z domu niewoli Polska nie utworzyła sobie ponownego pancerza formułek, i ponownego kaleczenia życia, żeby nie utworzyła państwa biurokratycznego i policyjnego, w którem jej życie będzie się rozbijało o ostre kanty narzuconego sobie aparatu państwowego" ${ }^{\text {"18 }}$. Wniesiony projekt zakładał trzyletnią kadencję Sejmu, uniemożliwial jego rozwiązanie przed terminem oraz odwoływanie przed terminem głowy państwa. Na trzyletnią kadencje miały być również wybierane sądy w wyborach powszechnych. Charakterystyczna była dopuszczona w projekcie możliwość wymagania od obywateli pracy na rzecz państwa oraz niezależność państwa od Kościoła. Poniatowski podkreślał, iż ustrój Polski powinien być atrakcyjny na zewnątrz, oparty o demokrację bezpośrednią i samorządność. W projekcie uzasadniał słuszność podatku progresywnego oraz zwracał uwagę na ryzyko stosowania nacjonalistycznej polityki na kresach, przestrzegając, że może to być "polityka zgubna"19. Podobnie jak we wcześniejszych latach dowodził, iż władza ustawodawcza powinna pozostać w rękach jednoizbowego Sejmu, a deklarację konstytucyjną Sejmu skrytykował za prowadzenie do państwa policyjnego (za czym miały przemawiać propozycje ustanowienia Straży Praw i uprawnienia głowy państwa) ${ }^{20}$.

W tym samym czasie, gdy toczyły się prace nad Ustawą Zasadniczą (Poniatowski zasiadał Komisji Konstytucyjnej, która ją przygotowywała, do czasu powołania w skład rządu, gdy w Komisji zastąpil go Jan Woźnicki), w ramach Komisji Rolnej dyskutowano priorytetową z punktu widzenia partii ludowej sprawę reformy rolnej. Większość członków Komisji stanowili przedstawiciele ugrupowań chłopskich („Wyzwolenie" początkowo reprezentowali B. Stolarski, Teofil Kurczak, Jan Smoła i Andrzej Waleron), co sprzyjało rozwojowi prac nad reformą. Między 19 marca a 22 maja $1919 \mathrm{r}$. opracowali oni projekt reformy rolnej za odszkodowaniem, określający maksymalna granice posiadania na 60-300 mórg ziemi. Za odszkodowaniem miały być upaństwowione także lasy. W Sejmie prace nad reformą nie posuwały się tak szybko, jak w Komisji i na plenum obrady nad „Uchwałą Sej-

${ }^{16}$ Sprawozdanie stenograficzne (dalej: Ss.) z 32. posiedzenia Sejmu Ustawodawczego z dnia 2 maja 1919 r., s. 60-61.

${ }^{17}$ Ss. nr 35, 9 V 1919 , s. 73-81.

${ }^{18}$ Ibidem, s. 71.

${ }^{19} \mathrm{~J}$. Jachymek, op.cit., s. 181.

${ }^{20}$ A. Kołodziejczyk, Ruch ludowy a Kościól rzymskokatolicki w latach II Rzeczypospolitej, Warszawa 2002 , s. 139. 
mu Ustawodawczego w przedmiocie zasad reformy rolnej" rozpoczęły się dopiero 3 czerwca. Kwestii tej poświęcono lącznie 21 posiedzeń21.

W imieniu PSL „Wyzwolenie” zabierali glos Poniatowski, B. Stolarski, J. Smoła, T. Kurczak, Jan Małupa i Romuald Wasilewski. Poniatowski w rzeczowych wystąpieniach podkreślał, że „posiadanie ziemi dla narodu jest kwestią narodowo ważną", przedstawiał przy tym dane statystyczne potwierdzające, iż wielka własność jest w większości zadłużona, szerzy się spekulacja ziemią i w związku z tym konieczne jest prawne uregulowanie tej kwestii. $W$ addzielnych przemówieniach wypowiadał się na temat dóbr donacyjnych, krytykował szkodliwy dla reformy rolnej handel ziemią, popieral parcelację dóbr martwej ręki a także sprzedaż ziemi bezrolnym, przy których zwracał uwagę, iż wprawdzie nie są wykształceni, co może negatywnie wpływać na ich kulturę rolną, jednak „jeżeli ktoś ma 4 morgi gruntu w 30 kawałkach, to [...] nawet gdyby posłać doktora agronomii na to gospodarstwo, to nie wiele większych cudów by dokazał od tego chłopa"22. Dla ludowców najważniejszą kwestią było określenie maksymalnej wielkości gospodarstw, pozostawianych w rękach jednego właściciela. Poniatowski w cytowanym wyżej przemówieniu stwierdzil, że najwydajniejsze są folwarki nie przekraczające 250-300 mórg ziemi.

- Propozycje Poniatowskiego nie znalazły wystarczającego poparcia, najbliższy im wniosek Komisji Rolnej określający wielkość gospodarstw od 60 do 300 mórg upadł, większości nie zyskał równieź wniosek posła Starzyńskiego określający na większości obszarów Rzeczypospolitej wielkość gospodarstw na 300 mórg (za i przeciw głosowała równa liczba posłów - 181), a marszałek sejmu nie zgodził się na propozycję Poniatowskiego, by wobec równej ilości głosów powtórzyć głosowanie nad wnioskiem Starzyńskiego. Dopiero na zebraniu przewodniczących Klubów Poselskich zdecydowano, by wniosek wrócił do Komisji Rolnej, dzięki czemu 10 lipca 1919 r. 183 głosami przeciw 182 (!) Sejm przyją ustalony na Komisji projekt uchwały o reformie rolnej, który był zmodyfikowanym projektem uchwały ludowców i określał wielkość gospodarstw nie podlegającą przymusowemu wykupowi na 107-321 mórg (60-180 ha ${ }^{23}$.

Ponieważ uchwała o reformie rolnej nie została wpisana do Dziennika Ustaw RP oraz nie miała podpisu Marszałka Sejmu, jej realizacja była jedynie postulatem, a nie obowiązkiem rządu. W związku $z$ tym w kolejnych miesiącach posłowie z PSL „Wyzwolenie” występowali z rezolucjami o jej realizację oraz regulowali problemy rolne na drodze oddzielnych wniosków sejmowych. 24 czerwca $1919 \mathrm{r}$. Poniatowski złożył w Sejmie wniosek w sprawie zabezpieczenia praw własności dla nabywców parcel gruntowych, których umowy i akty formalne potwierdzające własność nie zostały zakończone z powodu wojny ${ }^{24}$. Domagał się także utworze-

${ }^{21}$ Z. Hemmerling, op.cit., s. 93, 103.

${ }^{22}$ Ss. nr 50, 14 VI 1919, s. 36.

${ }^{23}$ AZHRL, A. Bogusławski, Wspomnienia, T. III (1919-1922), sygn. P-32, s. 12; A. Ajnenkiel, Historia sejmu polskiego, T. II, cz. II: II Rzeczypospolita, Warszawa 1989, s. 43.

${ }^{24}$ Ss. nr 54, 24 VI 1919, s. 49-50; S. Giza, op.cit., s. 55. 
nia Głównego Urzędu Ziemskiego, który miał realizować reformę rolną - Sejm przyjąt projekt 22 lipca $1919 \mathrm{r}^{25}$

Klub PSL „Wyzwolenie" dążył do jak najszybszego uchwalenia zarówno reformy rolnej, jak i konstytucyjnej, a w razie oporów Sejmu - do jego rozwiązania i przeprowadzenia nowych wyborów. Na Konwencie Seniorów 30 września $1919 \mathrm{r}$. Poniatowski wystąpił $z$ wnioskiem o przyjęcie projektu konstytucji w ciągu 6 tygodni, jednak wniosek został odrzucony. Głosowania nad konstytucją rozpoczęły się 21 października. "Wyzwolenie" zazwyczaj znajdowało się w mniejszości i jego wnioski upadały. Nie przeszedł wniosek Klubu, by osobę stojącą na czele państwa nazywać naczelnikiem państwa, upadł również projekt jednoizbowego parlamentu, a także wniesiona przez Poniatowskiego poprawka, by na kresach wschodnich wybierać jednego kandydata na 25 tys. mieszkańców, nie zaś na 50 tys., co zwiększyłoby prawdopodobieństwo, że kandydat będzie rzeczywiście znany w okręgu ${ }^{26}$. Wobec braku poparcia dla swoich projektów ustaw, pod koniec stycznia $1921 \mathrm{r}$. „Wyzwolenie" zdecydowało się na bojkot prac nad konstytucją, co jedynie ułatwiło prawicy przegłosowanie zgłoszonych przez ludowców poprawek. Pod koniec lipca 1921 r. Poniatowski pisał: „Ta zgnilizna, która się wkradła do rządów w Polsce, ta korupcja, która się rozwinęła, te rządy przypadkowe, nieodpowiedzialne muszą być zakończone, a mogą być zakończone tylko przy nowym Sejmie ${ }^{132}$. Postulował przyspieszenie prac nad konstytucją i zorganizowanie nowych wyborów, jednak nie zyskał poparcia. Poseł zdołał natomiast przekonać zgromadzony 26 października $1921 \mathrm{r}$. Sejm do przyjęcia nagłości wniosku w sprawie nadużyć policyjnych w Poznańskiem podczas strajków rolnych ${ }^{28}$.

Poniatowski zabierał głos także w kwestii budżetu państwa. Uważał, iż poprawę sytuacji finansowej i budżetu państwa można osiągnąć jedynie przez wprowadzenie podatków pośrednich, obciążających przede wszystkim kieszenie zamożniejszej części społeczeństwa ${ }^{29}$. Podobny wydźwięk miał wysunięty przez tegoż posła w listopadzie $1921 \mathrm{r}$. projekt daniny państwowej $\mathrm{z}$ progresywnym obciążeniem, bowiem jej ciężar przerzucał na grupy posiadające. Wobec odrzucenia poprawek Poniatowskiego, „Wyzwoleniowcy” krytykowali projekt rządowy ${ }^{30}$.

Choć większość poprawek, Wyzwolenia" nie znalazła poparcia, nie oznacza to, iż wszystkie byly błędne. Głoszenie postulatów jednoizbowego sejmu, zwiększenia roli samorządów i referendów czy bezpośredniego wyboru prezydenta, wynikały $z$ dążenia do zwiększenia roli demokracji bezpośredniej. Również propozycje wolności i równości wyznań nie były nierealne czy błędne $e^{31}$. Nie zdobywały one poparcia, bowiem w Sejmie przeważali nieprzychylni „Wyzwoleniu” posłowie prawicowi.

\footnotetext{
${ }^{25}$ Ss. nr 75, 22 VII 1919, s. 25-28.

${ }^{26}$ Ss. nr 103, 25 XI 1919, s. 3-6.

${ }^{27}$ Ss. nr 245, 30 VII 1921, s. 117.

${ }^{28}$ Ss. nr 257,26 X 1921, s. 38.

${ }^{29} \mathrm{Ss} . \mathrm{nr} 141,27$ IV1920, s. 3-17.
}

${ }^{30} \mathrm{Z}$. Hemmerling, op.cit., s. 120 ; Z. Wasik, Wplyw ugrupowán politycznych na funkcjonowanie parlamentu II Rzeczypospolitej (1921-1935), Toruń 1993, s. 63-65.

${ }^{3 !} Z$. Hemmerling, op.cit., s. 108-110. 
Po początkowej pomyślnej ocenie wyników wyborów sejmowych, już w kwietniu 1919 r., gdy Poniatowski dolączyl do prac parlamentarnych, ich ocena w szeregach klubu „Wyzwolenia” była zdecydowanie negatywna. Zdobyta przez „Wyzwole. nie" ilość mandatów okazała się niewystarczająca, by przeprowadzić próby reform sabotowanych przez prawicową większość. Głównym dążeniem Poniatowskiego caly czas bylo przeprowadzenie reformy rolnej. Oburzało go, że parcelacja majątków przekraczających 180 ha była fikcją, a w całym kraju trwała niekontrolowana i niezwiązana $z$ uchwałą Sejmu dzika parcelacja. Do połowy 1920 r. nie wywłaszczono ani jednego hektara ziemi folwarcznej, a majątki państwowe przeznaczone do parcelacji obejmowały jedynie grunty o niskich klasach ${ }^{32}$. Poniatowski rozważał możliwość rozwiązania Sejmu i przeprowadzenia nowych wyborów. Posłom „Wyzwolenia" zabrakło umiejętności i chęci wchodzenia w koalicje, by osiągać przynajmniej częściowe cele. Skutkowało to niskim poparciem dla zgłaszanych przez tą partię ustaw i wniosków, na co $\mathrm{z}$ kolei posłowie $\mathrm{z}$ tego stronnictwa niejednokrotnie reagowali w czasie obrad gwizdami i biciem w pulpity. Pełne poparcie reprezentowali poslowie „Wyzwolenia” jedynie dla decyzji politycznych J. Piłsudskiego.

Pod wplywem części posłów, m.in. M. Rataja oraz na skutek dążeń wsi do zjednoczenia i zdobycia parlamentarnej większości, 13 lutego 1919 r. Klub PSL "Wyzwolenie" zorganizował spotkanie posłów ludowych $z$ różnych klubów, poświęcone kwestii zjednoczenia. 23-24 lutego w Warszawie odbył się m.in. z udziałem Poniatowskiego zjazd "Wyzwolenia”, na którym dyskutowano to zagadnienie. Poniatowski, podobnie jak wielu innych posłów "Wyzwolenia" miał negatywny stosunek do Witosa, uważał go za przedstawiciela bogatych chłopów. Jednak chłopi zgromadzeni na Kongresie wyrazili wolę zjednoczenia, toteż 23 czerwca $1919 \mathrm{r}$. powołany został Związek Sejmowy Klubów Stronnictw Ludowych (ZSKSL).

Związek, $z$ daniem ludowców $z$ „Wyzwolenia”, miał walczyć o reformę rolną, zespolenie Wielkopolski z resztą ziem Polski, zlikwidowanie Komitetu Narodowego Polskiego w Paryżu oraz poparcie federacyjnej polityki Piłsudskiego. Ponieważ jego stworzenie dawało nadzieję na zrealizowanie reformy rolnej, nawet przeciwnicy zjednoczenia, do których zaliczał się Poniatowski, poparli ostatecznie jego powstanie. Na posiedzeniu Rady Naczelnej PSL 31 sierpnia 1919 r. Poniatowski potwierdził, iż „dla należytego wprowadzenia reformy rolnej, jak również dla przeprowadzenia w Sejmie konstytucji po myśli ludu potrzeba zjednoczyć wszystkie sily ludowe" ${ }^{n 33}$. W wyniku uchwał Rady 8 października 1919 r. przekształcono ZSKSL w Klub Sejmowy Ludowców złożony z posłów „Piasta” i „Wyzwolenia”. W wybranym 15 października zarządzie Klubu Witos został wybrany prezesem, Rataj wiceprezesem, Jan Dąbski sekretarzem, natomiast w 12-osobowym prezydium znalazl się m.in. Poniatowski ${ }^{34}$. Mimo to większość w nowym klubie stanowili ludowcy z „Piasta”, co nie podobało się grupie posłów skupionych wokół

${ }_{32}^{32}$ Ibidem, s. 79, 99; A. Kołodziejczyk, Ruch ludowy..., s. 193.

${ }^{33}$ AZHRL, A. Bogusławski, T. III, op.cit., s. 24.

${ }^{34}$ A. Zakrzewski, Sejmy - kluby - postowie, [w:] Sejmy drugiej Rzeczypospolitej, pod red. A. Zakrzewskiego, Warszawa 1990, s. 184; Z. Hemmerling, op.cit., s. 87; S. Giza podaje, iż wybory mialy miejsce 16 X (S. Giza, op.cit., s. 57). 
S. Thugutta. 22 stycznia 1920 r. 23 posłów, w tym m.in. I. Poniatowski, K. Bagiński, I. Dziubińska, I. Kosmowska, B. Stolarski i A. Waleron wystąpili ze wspólnego klubu i utworzyli znów oddzielny - PSL „Wyzwolenie”. Bezpośrednią, oficjalną przyczyną takiej decyzji, byly rozmowy W. Witosa i M. Rataja $z$ Narodowym Zjednoczeniem Ludowym w sprawie utworzenia rządu, przede wszystkim ustępstwa w sprawie zasad reformy rolnej, konstytucji i utworzenia senatu ${ }^{35}$. „Sumienie powiedziało nam: nie wolno polityki ludowej wprowadzać w błoto oszukańczych i tanich ustępstw [...], nie łakomić się na ochłapy"36. Prywatne motywy posłów mogły być jednak inne, np. Poniatowski miał ponoć w kuluarach przyznać, iż połączenie klubów mu nie odpowiada, bowiem Wyzwolenie straci stanowiska i wpływy, gdyż Piastowcy "nas nie postawią na listy przy wyborach" ${ }^{37}$.

Tymczasem "Wyzwolenie" znów podjęło starania o zrealizowanie reformy rolnej. W marcu Sejm przyjął ustawę w sprawie dzierżawy odłogów z poprawkami Poniatowskiego, w maju przyjęta została z jego poprawkami ustawa o likwidacji serwitutów, zaś 23 kwietnia 1920 r. Poniatowski złożył nagły wniosek w Sejmie w sprawie przyspieszenia wykonania uchwały o reformie rolnej (chciał, by rząd w ciągu tygodnia przedstawil swoje projekty reformy) ${ }^{38}$.

W lipcu tegoż roku Poniatowski został ministrem rolnictwa w rządzie Witosa. Jako minister starał się doprowadzić do przekazania od 15 września odłogów folwarcznych na 4-letnią dzierżawę chłopom, odłogi miały być wskazywane przez rady gminne. Wbrew pozytywnym artykutom tygodnika "Wyzwolenie" informującym czytelników, ze „W Ministerium Rolnictwa widzi się dziś znaczące ożywienie $^{\text {"39 }}$, nie przyspieszyły tempa prace nad reformą rolną. Przyznawał to sam Poniatowski, który zwracał uwagę, iż „dotychczas obowiązkiem Ministerstwa Rolnictwa jest dbać o to, ażeby Glówny Urząd Ziemski mial co parcelować" ${ }^{\prime \prime}$, ale jest ograniczony ustawą, której musi przestrzegać. Charakterystyczne jest jednak, iż choć $w$ czasie pełnienia funkcji ministra Poniatowski rzadko wypowiadał się w debatach sejmowych, pierwsze wystąpienie od chwili utworzenia rządu poświęcił właśnie parcelacji. 19 listopada 1920 r. wyjaśniał, iż rzą miał prawo rozparcelować dobra „martwej ręki” przepisane aktami hipotecznymi na państwo ${ }^{4 !}$.

Poniatowski nie brał udziału w głosowaniach imiennych nad konstytucją, które mialy miejsce w czasie, gdy był ministrem. Dnia 17 lutego $1921 \mathrm{r}$. PSL „Wyzwolenie" odwołało Poniatowskiego z rządu i przeszło do opozycji względem rządu Witosa $^{42}$. Decyzję rezygnacji z teki ministra Poniatowski argumentował uspokoje-

${ }^{35}$ Z. Hemmerling, op.cit., s. 88-89.

${ }^{36}$ Bracia, Ludowcy!, Wyzwolenie. Pismo tygodniowe, polityczne, społeczne i gospodarcze. Organ Polskiego Stronnictwa Ludowego (dalej: Wyzwolenie), R. VII, Nr 7, 15 II 1920, s. 91.

${ }^{37}$ AZHRL, A. Bogusławski, T. III, op.cit., s. 29.

${ }^{38}$ Ss. nr 131, 18 III 1920; Ss. nr 145, 7 V 1920; Ss. nr 139, 23 IV 1920, s. 3.

${ }^{99} Z$ Ministerium Rolnictwa, Wyzwolenie, R. VII, Nr 32, 8 VIII 1920, s. 353.

${ }^{40}$ Ss. nr 187, 19 XI 1920, s. 60-63.

4) Ibidem; J. Borkowski, Ludowcy..., s. 121.

${ }^{42}$ W. Stankiewicz, Ruch ludowy w pierwszych latach niepodleglosci, [w:] J. Borkowski i in., Zarys historii polskiego ruchu ludowego, T. II (1918-1939), Warszawa 1970, s. 72. 
niem sytuacji zewnętrznej, związanym z planowanym podpisaniem pokoju w Rydze oraz koniecznością „ułożenia” współpracy poszczególnych stronnictw, bez czego nie była możliwa, jego zdaniem, realizacja zadań rządu przez przedstawicieli tworzących go ugrupowań ${ }^{43}$. Ważniejszym powodem były zapewne złe stosunki między PSL „Wyzwolenie” a PSL „Piast”.

Na przełomie maja i czerwca $1922 \mathrm{r}$. wiodącym tematem na łamach tygodnika „Wyzwolenie", jak również w ramach obrad sejmowych była kwestia wykupu majątku Dojlidy przez Polsko - Amerykański Bank Ludowy w Krakowie. 4 kwietnia 1922 r. poseł Witold Staniszkis wniósł interpelację przeciwko posłowi PSL „Piast” dr Władysławowi Kiernikowi, byłemu prezesowi Głównego Urzędu Ziemskiego (GUZ), zarzucając mu nadużycie swojego mandatu poselskiego. W sprawie zabierał głos m.in. Poniatowski twierdząc, iż Bank Polsko - Amerykański jest instytucją spekulacyjną, więc prezes GUZ powinien się sprzeciwić przeprowadzonej przez Bank transakcji. Zgłosił również wnioski, by rząd unieważnił upoważnienia wszystkim instytucjom parcelacyjnym oraz potępił udzielenie zezwolenia na sprzedaż majątku Dojlidy44. Ostatecznie Kiernik został uniewinniony przez sąd marszałkowski, jednak „Wyzwolenie” przez dlugi czas przypominało sprawę Dojlidy, jako świađczącą negatywnie o PSI „Piast"45.

O ile sympatie względem „Piasta” były w ramach „Wyzwolenia” słabe i zmienne, niekwestionowanym autorytetem dla tejże partii pozostawał J. Piłsudski. Objawiło się to choćby w lipcu $1922 \mathrm{r}$, gdy Związek Ludowo-Narodowy złożył wniosek nagły o wyrażenie votum nieufności Naczelnikowi Państwa. $W$ dyskusji nad wnioskiem zabrał głos między innymi Poniatowski oświadczając: „Caly bez mała naród polski widzi w Józefie Piłsudskim, pierwszym Naczelniku odrodzonego państwa naszego symbol czynnej, zwrycięskiej walki o niepodległość, uosobienie cnoty obywatelskiej i dochodzącej do zupełnego zaparcia się ofiarności". Wniosek o wotum nieufności nazwał z kolei „przesiąkniętą złą wolą i pozbawioną poczucia odpowiedzialności nową próbą zamachu na ustalający się porządek prawno - państwowy [co] zmusza nas do wyrażenia pogardy dla tego rodzaju walki" ${ }^{46}$. W głosowaniu imiennym 186 osób opowiedziało się za wnioskiem, zaś 206 przeciwko, co wywołało huczne manifesty na lewicy na cześć Marszałka.

5 listopada 1922 r. odbyły się wybory do Sejmu I kadencji, w wyniku których Poniatowski w grupie 49 posłów ,Wyzwolenia" ponownie otrzymał mandat (tym razem z okręgu nr 9: Płock, Płońsk, Sierpc, Rypin), a 2 grudnia został wicemarszałkiem izby poselskiej 255 głosami, co może świadczyć o sporym zaufaniu do tego posła $^{47}$. W grudniu otrzymał także propozycję przyjęcia teki ministra rolnictwa

${ }^{43}$ W. Witos, Wybór pism, wstęp i oprac. J. Borkowski, Warszawa 1989, s. 118-119.

${ }^{14}$ AZHRL, A. Bogusławski, T. III, op.cit., s. 171-73; Ss. nr 296, 4 IV 1922, s. 83, 98.

${ }^{45}$ Reforma rolna $w$ Sejmie. Piastowcy razem $z$ prawica cheq odebrać nadzieje otrzymania ziemi obszarniczej. Dojlidziarz - piastowiec Makulski nie ma wstydu, Wyzwolenie, R. XII, Nr 26, 28 VI 1925 , s. 3-4.

${ }^{46}$ Ss. nr 330,26 VII 1922 , s. 20.

${ }^{47}$ AZHRL, Zyciorysy działaczy ludowych, sygn. Z-50, s. 223; Ss. nr 3, 2 XII 1922; S. Giza błędnie podaje, iż nastąpiło to 1 XII 1922 (S. Giza, op.cit., s. 68). 
w rządzie Władysława Grabskiego, jednak nie chciał się zgodzić na uczestniczenie w. rządzie, w którym zasiadałby przedstawiciel Związku Ludowo-Narodowego ${ }^{48}$.

W tej kadencji Poniatowski przemawiał w sprawie ustaw, interpelowal oraz stawiał wnioski na 79 posiedzeniach, czasami zabierał głos kilka razy w czasie jednego posiedzenia, a samych przemówień wygłosił $59^{49}$. W liczbie tej nie uwzględniam wystąpień związanych z pełnioną przez niego funkcją wicemarszałka.

W marcu i kwietniu 1923 r. Poniatowski uczestniczył w dyskusjach nad projektami ustaw o zwalczaniu lichwy wojennej, o podatku gruntowym, o daninie lasowej oraz o powiększeniu do 2 miliardów marek gwarancji na pożyczki dla drobnych przemysłowców i rzemieślników oraz ich organizacji wytwórczych. Deklarowal przy tej okazji, iż chłopi zdają sobie sprawę, jak konieczne są nakłady rolnictwa na rozwój przemysłu w celu zmniejszenia przeludnienia wsi i zgadzają

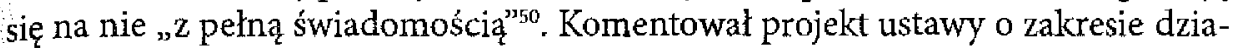
kania ministra reform rolnych, podatku majątkowego, a także parcelacji i osadnictwa. Uzasadniał także naglości wniosków „Wyzwolenia”, m.in. w sprawie zakazu eksportu drzewa. Na początku 1924 r. Poniatowski występował w dyskusji nad projektem ustawy o zabezpieczeniu na wypadek bezrobocia, a w czerwcu zgłaszał swoje poprawki do budżetu Ministerstwa Rolnictwa i Dóbr Państwowych. W czerwcu 1924 r. Poniatowski zabrał również głos w kwestii sądownictwa zwracając uwagę, iż wymierzanie sprawiedliwości z kilkuletnim opóźnieniem przyczynia się do zmniejszenia $z$ każdym rokiem autorytetu sądów $w^{51}$. Ten krótki przegląd stanowi jedynie zarys ważniejszych zagadnień poruszanych przez Poniatowskiego w Sejmie i świadczy o jego niebywałej aktywności poselskiej.

Większość poprawek Poniatowskiego była odrzucana przy głosowaniu. Przy* czyną, obok braku poparcia dla projektów PSL „Wyzwolenie" w lawach sejmowych, był zbytni radykalizm wielu $z$ proponowanych przez Poniatowskiego ustaw. Sprawozdawca ustawy celnej Gościcki w lipcu 1924 r. zarzucił Poniatowskiemu, iż nie liczy się dostatecznie ze wszystkimi praktycznymi względami i warunkami, które trzeba brać pod uwagę ${ }^{52}$. Wydaje się jednak, iż Poniatowski był świadom ograniczeń nakładanych przez warunki, był jednak zbyt bezkompromisowy, by z powodu względów praktycznych rezygnować ze stawianych sobie politycznych celów.

Najistotniejszym osiagnięciem Poniatowskiego w tym czasie było przygotowanie własnego projektu reformy rolnej. Nim został opracowany konieczne były pewne kroki przygotowawcze. Wiosną $1924 \mathrm{r}$. na forum Sejmu toczyła się debata nad projektem ustawy o scalaniu gruntów. Z ramienia PSL „Wyzwolenie” głos zabierał m.in. Poniatowski, zwracając uwagę na konieczność otwarcia długoterminowego kredytu, a także 4-procentowego kredytu na pomiary gruntu, melioracje i przebudowę gospodarstw, zakładania hipotek, a także prawo do pożyczki z Państwowego

\footnotetext{
${ }^{48}$ S. Lato, Ruch ludowy w akresie najwiekszego rozbicia, [w:] Zarys historii..., s. 126.

${ }^{49}$ Z. Hemmerling, op.cit., s. 150.

so Ss. nr 26, 17 III 1923, s. 51.

${ }^{51}$ J. Jachymek, op.cit., s. 123.

${ }^{52}$ Ss., nr 142, 3 VII 1924, s. 71.
} 
Banku Rolnego oraz zwolnienie scalonych osad na dwa lata od podatku gruntowego ${ }^{53} .31$ lipca $1923 \mathrm{r}$. Sejm uchwalił powyższą ustawę, jednak nie przyczyniła się ona do zwiększenia skali komasacji. $Z$ tego względu już w 1925 r. rozpoczęła się sejmowa debata nad rządowym projektem nowelizacji ustawy. Uczestniczący w niej z ramienia swej partii Poniatowski postulował przenieść ciężar komasacji jak najniżej, tworzyć komisje miejscowe, które rozszerzą obszar komasowanych ziem na grunta folwarczne. Whioski te miały ułatwić i przyspieszyć komasację, jednak propozycja, aby przy pracach scaleniowych włączyć do obszaru wsi przyległe grunta folwarczne, nie zyskała poparcia. Mimo to w ciągu 3 lat po uchwaleniu ustawy skomasowano większy obszar (prawie 147 tys. gospodarstw o obszarze 1165,6 tys. ha) niż w latach 1919-1925 przed jej wprowadzeniem ${ }^{54}$.

Przygotowaniem do ustawy o reformie rolnej była równiež ustawa o regulacji stosunków wodnych. Poniatowski szacował, iż dzięki melioracji nieużytków można uzyskać 1,5 do 2 mln ha na cele reformy, wzrosną plony i zmaleje ryzyko powodzi $i^{55}$.

3 marca 1924 r. Poniatowski odbył konferencję $z$ M. Ratajem w sprawie planu prac sejmowych, na której między innymi omawiano, czy ustawę o parcelacji i osadnictwie wprowadzić z powrotem na porządek dzienny. Poniatowski był w tym czasie zdania, iż lepiej odroczyć ustawę, by rząd mial czas zgłosić swoje poprawki, tym bardziej, iż stan budżetu paristwa uniemożliwiał przeprowadzenie reformy rolnej w tej formie, jaką przewidywano w 1919 i 1920 r. „Szukamy sposobu sfinansowania reformy rolnej, jeśli nie znajdziemy, trzeba będzie pójść na parcelację pod nadzorem $\mathrm{i}$ kierownictwem państwa" - zanotował w tym czasie Rataj $^{55}$. Już 11 kwietnia 1924 r., J. Poniatowski wystąpil w Sejmie $z$ wnioskiem nagłym, w którym domagał się wykonania reformy rolnej. Jednocześnie przedstawił projekt „Ustawy o wykonaniu reformy rolnej”, którego był autorem.

Ustawa przypominała w swych założeniach projekt $z 15$ lipca $1920 \mathrm{r}$. i opierała się na założeniu, że parcelacja państwowa może zbliżyć obywateli do państwa, podczas gdy prywatna nie posiada takich walorów. Głównym jej celem było jednorazowe upaństwowienie większych obszarów, w tym lasów i wód, wbrew opinii części działaczy partii, za odszkodowaniem (określonym przez właścicieli przy wyliczaniu podatku dochodowego, wypłacanym listami „Państwowej Renty Ziemskiej” lub „Leśnej”), w celu stworzenia jak największej liczby samodzielnych gospodarstw. W pobliżu miast zakładał przejęcie przez państwo ziem, jeśli majątki przekraczałyby 30 ha, natomiast na innych obszarach kraju przejęte miały być nadwyżki powyżej 60 ha. $Z$ reformy nie wykluczał majątków kościelnych - w tym wypadku majątki mogły liczyć do 5 ha. $Z$ uzyskanych tą drogą 2,4 do 5 mln ha ziem proponowal stworzyć nowe, samodzielne gospodarstwa rolne lub ogrodniczo-warzywne, zwiększać obszar gospodarstw karłowatych, a także two-

\footnotetext{
${ }^{53}$ Ibidem, s. 63.

${ }^{54}$ Ss. nr 193, 3 IV 1925, s. 58.

${ }^{55}$ J. Jachymek, op.cit., s. 64.

${ }^{56}$ M. Rataj, op.cit., s. 191.
} 
rzyć kolonie i ogródki robotnicze w pobliżu miast, przy czym nowotworzone gospodarstwa nie mogłyby przekraczać 15 ha. Na ziemiach z parcelacji proponował również tworzyć szkoły rolnicze i ośrodki doświadczalne w dziedzinie agrotechniki, ogrodnictwa, sadownictwa. W swym projekcie Poniatowski pozostawił właścicielom ziem swobodę wyboru, które części majątku zostaną rozparcelowane, określal jednak sztywno procedurę i czas parcelacji (Okręgowe Urzędy Ziemskie zobowiązywał do rozpatrzenia wskazanych nadwyżek w okresie 2 tygodni, w razie ich zatwierdzenia miały kolejnych 10 dni na wpisanie ich do ksiąg hipotecznych), przewidywał również przyznanie bezpłatnie gruntów inwalidom i żołnierzom. Nabywcy bezrolni mieli przy nabyciu płacić $5 \%$ wartości gruntów, resztę ich wartości natomiast mieli spłacać przez kolejne 35 lat przy 3,5\% oprocentowaniu (malorolni $10 \%$ gotówką, resztę ratalnie przez 30 lat, samodzielni - $50 \%$ gotówką, połowę zaś z pomocą 3-letniego kredytu) ${ }^{57}$.

Projekt Poniatowskiego został złożony w Sejmie jako wniosek nagły, rząd nie zdecydowal się jednak postawić tego wniosku pod obrady Sejmu. Przyczynił się do tego poseł Witold Staniszkis ze Związku Ludowo-Narodowego, który wystąpił przeciwko nagłości wniosku. Argumentował, iż ważniejsze jest stworzenie możliwości przeprowadzenia ustawy, a nie szybkie uchwalenie nowego projektu. Dowodził, iż wniosek Poniatowskiego nie przyspiesza ustawy, bowiem „czynnikiem decydującym o przechodzeniu ziemi w ręce drobnej własności jest sprawa kredytu". Rozumial przez to możliwość uzyskania kredytów długoterminowych przez większą własność, której nie wolno sprzedawać ziemi za gotówkę, choć ma być od niej pobrany podatek majątkowy. Podkreślał także, iż „nie koniecznie odpowiadał rzeczywistości" szacunek wartości majątków określany w celach majątkowych, mający w projekcie Poniatowskiego stanowić podstawę określania cen parcelowanych gruntów.

Po wystąpieniu Staniszkisa nastąpiło głosowanie, w którym wniosek 147 głosami przeciwko 117 wniosek został odesłany do Komisji Rolnej. Przy sprzeciwie prawicy wniosek nie miał wystarczającego poparcia w sejmie, by powrócić na obrady plenarne. Na znak protestu przeciwko blokowaniu wejścia pod obrady Sejmu projektu reformy rolnej, Poniatowski zrzekł się funkcji przewodniczącego komisji rolnej, którą w tym czasie pelnit ${ }^{58}$.

Projekt zaproponowany przez Poniatowskiego nie był jedynym, nad którym pracował Sejm. Już 12 grudnia 1923 r., po kilku miesiącach dyskusji w łonie rządzącej ówcześnie koalicji, pod obrady Sejmu trafil projekt, w którym przewidywano, iż właściciele folwarków będą oddawać ziemię na parcelację dobrowolnie i dopiero przy braku zgłoszeń minimum parcelacyjne 200 tys. ha rocznie będzie uzupełniane z ziem przymusowo wykupionych, jednak propozycje te spotkały się $z$ ostrą krytyką wśród partii lewicowych ${ }^{59}$. Poniatowski zgłosił w czasie obrad, by

${ }^{57}$ Z. Hemmerling, op.cit., s. 165-168; J. Jachymek, op.cit., s. 37, 40-43.

${ }^{58} \mathrm{~S}$. Lato, Ruch ludowy w okresie największego rozbicia, op.cit., s. 140.

${ }^{59} \mathrm{~J}$. Ciepielewski, Stronnictwa i partie polityczne wobec kwestii rolnej $i$ chlopskiej w Polsce międzywojennej, Warszawa 1969, s. 35. 
Sejm przeszedł nad projektem do porządku dziennego, a Komisja Sejmowa przygotowała nowy projekt ustawy, jednak Sejm propozycję Poniatowskiego odrzuciłso.

14 czerwca $1924 \mathrm{r}$. minister reform rolnych Zdzisław Ludkiewicz przedstawił nowy projekt, jednak szybko odszedł ze stanowiska, a Wiesław Kopczyński, który objął po nim tekę, wycofał projekt poprzednika i zapowiedział zgłoszenie własnego, co nastąpilo 19 lutego 1925 r. Projekt Kopczyńskiego kładl nacisk na parcelację prywatną oraz określał znacznie wyższą górną granicę posiadania, przewidzianą na 180-400 ha, dlatego spotkat się ze zdecydowaną krytyką stronnictw ludowych, a szczególnie Poniatowskiego, który stwierdził, iż rząd sam nie wierzy w możliwość przeprowadzenia reformy i jedynie odwołuje się do dobrej woli obszarników, bowiem to oni mieli ustalać ceny parcelowanych gruntów. $Z$ tego powodu Poniatowski zglosił wniosek o odrzucenie projektu ustawy, który jednak nie zyskał szerszego poparcia poza „Wyzwoleniem”61.

$\mathrm{Na}$ forum sejmowym właściwa dyskusja nad reformą rolną trwała od połowy czerwca do początków lipca, a Poniatowski był jej najaktywniejszym uczestnikiem, zabierał bowiem w tej sprawie głos aż 16 razy na 120 wygłoszonych przemówień (tylko 3 lipca miał w trakcie obrad 7 wystąpień szczególowych) ${ }^{62}$. Nie wszystkie jego wystąienia godne były posła. Przykład niezbyt chlubny jego parlamentarnej działalności odnotowal Rataj 19 czerwca 1925: „w czasie dyskusji ciągle burzliwe incydenty. Przy głosowaniu w drugim czytaniu zaczęła się obstrukcja imiennymi głosowaniami, wysuwaniem formalnych zagadnień. Głównie Wyzwolenie, a jego imieniem wicemarszałek Poniatowski ${ }^{n^{63}}$. Również kilka miesięcy później krytyczny względem dawnego klubowego kolegi pamiętnikarz zanotował, iż Poniatowski wykorzystywal pełnioną funkcję przy głosowaniu poprawek Senatu do reformy rolnej. „Wyzwolenie obstruuje sprawami formalnymi, imiennymi głosowaniami, a wreszcie awanturami, wskutek których posiedzenie przerwano i odroczono do 5 listopada. Awantury zresztą na zimno. Wicemarszałek Poniatowski prowadzi harce przeciw regulaminowi" ${ }^{\prime \prime 4}$.

W Sejmie, przy zdecydowanym poparciu większości posłów, ustawę o reformie rolnej przegłosowano 20 lipca $1925 \mathrm{r}$. Wśród PSL „Wyzwolenie” nie było pełnej jednomyślności, wielu członków Klubu było nieobecnych na głosowaniu. Posłowie $z$ "Wyzwolenia", w tym Poniatowski, mimo przekonania o konieczności przeprowadzenia reformy rolnej, woleli odrzucić całą ustawę, niż ustąpić w pewnych kwestiach ${ }^{65}$. Z perspektywy lat Poniatowski krytyeznie wypowiadał się o reformie rolnej uważając, iż nie spełniła ona pokładanych w niej nadziei oraz nie została zrealizowana w planowanym zakresie, bowiem „było nie dość powszechne przekonanie społeczeństwa o jej konieczności i celowości" ${ }^{\text {"66 }}$.

${ }^{\text {s0 }}$ A. Kołodziejczyk, op.cit., s. 203.

${ }^{61}$ J. Jachymek, op.cit., s. 48-52; S. Lato, op.cit,, s. 162-163.

${ }^{62} \mathrm{Z}$. Hemmerling, op.cit., s. 170.

${ }^{63}$ M. Rataj, op.cit., s. 331.

${ }^{64}$ Ss. nr 248, 5 XI 1925, s. 6, 9; M. Rataj, op.cit., s. 340.

${ }^{55}$ Ss. nr 234, 14 VII 1925, s. 3-10.

${ }^{56}$ J. Poniatowski, Cele i zatożenia Reformy Rolnej w 20-leciu, wstęp i oprac. J. Górecki, Warszawa 2004 , s. 31 . 
Poniatowski nie był zadowolony z kształtu i prac Sejmu. W październiku tego roku zabrał głos w kwestii obronności kraju stwierdzając, iź jeśli wojsko jest „traktowane jako oręż polityczny, to możemy mieć wszelkie prawo mniemania, że i najszczęśliwsza nawet polityka zagraniczna państwa Polskiego nie zapewni mu dostatecznego bezpieczeństwa" ${ }^{\text {"67 }}$. Krytykował również personalnie niektórych posłów, 30 października 1924 roku Poniatowski zabrał głos w sprawie rządu Władysława Grabskiego, domagał się ustąpienia $\mathrm{z}$ jego gabinetu aż 4 ministrów, w ostrych słowach zaatakował Władysława Sikorskiego ${ }^{68}$. Rataj zauważyl, iż wystąpienie to mogło być inicjowane przez Sulejówek i samego Grabskiego, który jego zdaniem widział w Sikorskim konkurenta do funkcji premiera ${ }^{69}$.

W dążeniu do „czystości” Sejmu Poniatowski nie cofał się przed argumentami mogącymi uderzyć bezpośrednio w niego. 27 listopada 1924 r. wystąpił z pismem wskazującym, iż wicemarszałek Władysław Seyda jest adwokatem przemysłu górnośląskiego i w tej roli nieraz występuje wobec rządu, co jest niedopuszczalne wobec faktu, iż jest on jednocześnie wicemarszałkiem. Zagroził w związku $z$ tym swoją rezygnacją z funkcji wicemarszałka, jeśli sprawa nie zostanie wyjaśniona, argumentując, iż "nie zawsze zasiadanie w prezydium Sejmu jest zaszczytem"70. Aby wyjaśnić sytuację Rataj zaprosil wicemarszałków na poufną konferencję. Zanotował po niej, że "Pan Poniatowski z tępym uporem, który go charakteryzuje, upierał się przy decyzji natychmiastowej" ${ }^{71}$. Ostatecznie Poniatowski zgodził się nie wszczynać przez miesiąc żadnych kroków i Seyda zrezygnowal z funkcji wicemarszałka.

Dążenie do czystości Sejmu, tak podkreślane prze Poniatowskiego, stanowiło jego zdaniem cel zamachu Piłsudskiego, mimo iż Komendant na zorganizowanej „herbatce” dla posłów powiedział „mogłem nie dopuścić Was do Zgromadzenia Narodowego, kpiąc $z$ was wszystkich, ale czynię próbę, czy można jeszcze rządzić w Polsce bez bata"72. Poniatowski zdecydowanie poparł zamach majowy. Na zebraniu Rady Naczelnej PSL „Wyzwolenie" 23 maja 1926 r. wygłosił referat o sprawach organizacyjnych, w którym uznawał go za nieuniknioną konieczność, powstałą w „warunkach wytworzonych przez rząd PSL „Piast”, Narodowej Demokracji i Chrześcijańskiej Demokracji. Czyn zbrojny Piłsudskiego należy widzieć jako zbawienny dla dalszych losów Polski, zaś Piłsudski powinien zostać prezydentem państwa'"

Działacze „Wyzwolenia" oczekiwali, iż w panującej sytuacji Piłsudski rozwiąże parlament i zarządzi nowe wybory, Poniatowski uważal, że dalsze utrzymywanie

${ }^{67}$ Ss. nr $157,20 \times 1924$, s. 26.

${ }^{68}$ M. Rataj, op.cit., s. 244; J, Borkowski, op.cit., s. 222.

${ }^{59}$ M. Rataj, op.cit., s. 252.

${ }^{70}$ Ibidem, s. 254.

"Ibidem, s. 255, 262.

${ }^{72}$ A. Ajnenkiel, Sejmy i konstytucje w Polsce 1918-1939, Warszawa 1968, s. 78.

${ }^{73}$ S. Lato, Ewolucja Polskiego Stronnictwa Ludowego Wyzwolenie po zamachu majowym $1926 \mathrm{r}$, [w: Studia $z$ dziejów ruchu ludowego. 1969. Ofiarowane Czesławowi Wycechowi w 70 . rocznicę urodzin, Warszawa 1969, s. 176-177. 
Sejmu jest marnowaniem entuzjazmu, który po przewrocie nastąpił w społeczeń stwie. Jednak rozwiązanie parlamentu nie nastąpiło ${ }^{74}$.

Dwa miesiące po zamachu majowym, 17 lipca $1926 \mathrm{r}$. w Sejmie debatowano nad zmianą konstytucji. Tradycyjnie w kwestiach kodyfikacyjnych głos zabrał Poniatowski. „Nie uważamy za słuszne, alby Sejm obecny zajmował się istotną naprawą dotychczasowej Konstytucji, albowiem na to nie pozwalają ani jego kwalifikacje rzeczowe, ani opinia, którą ma niestety w kraju ustaloną"7s. Poniatowski był przeciwny uchwaleniu nowej konstytucji, jednak uznał za wskazane zmienić niektóre wcześniejsze zapisy. Przywołał przy tym przede wszystkim kwestię zbęd. nego jego zdaniem Senatu, proponowal zdecydowanie ograniczyć jego rolę przy uchwalaniu budżetu.

Poniatowski często zwracal uwagę na zachowanie powagi i czystości Sejmu, ale potrafił dla swych przekonań omijać funkcjonujące w nim zakazy formalne. 30 września 1926 roku, gdy większość sejmowa głosowała w prowizorium budżetowym poprawki Senatu skierowane przeciw rządowi, PSL „Wyzwolenie” opowiedziało się za rządem. Ugrupowanie wnioskowało o rozwiązanie Sejmu, widząc w tym wyjście $z$ patowej sytuacji. Sejm nie mógł się sam rozwiązać, jednak Poniatowski dzięki umiejętnie skonstruowanemu wnioskowi złożył postulat, by rząd zaproponował prezydentowi RP rozwiązanie Sejmu. Rataj byl przeciwny wnioskowi, uważał za niewłaściwe „petycjonowanie i to za pośrednictwem rządu będącego w dymisji". Konstrukcja wniosku była jednak taka, iż Rataj musiał go uznać za dopuszczalny. Nad wnioskiem glosowano na kolejnym posiedzeniu, ale nie przeszedł. Rząd podał się do dymisji ${ }^{76}$.

Gdy w „Głosie Prawdy” opublikowano artykuł, iż poseł Sylwester Wojewódzki był płatnym agentem, Poniatowski domagał się w interesie Sejmu wyjaśnienia sprawy. Sprawę tę miał rozpatrzyć sąd marszałkowski, w którym zasiedli m.in. Poniatowski i Ignacy Daszyński, krytykowani przez Wojewódzkiego za stronniczość. Nieprzychylny Poniatowskiemu Rataj przyznal w swych pamiętnikach, iż „Wątpliwości co do obiektywizmu p. Poniatowskiego nie były uzasadnione, doszedłem do tego przekonania przysłuchując się częściowo przewodowi sądowemu"77: Pamiętnikarz przyznał również, iż Poniatowski na Konwencie 30 października 1926 roku złożył w „sprytny" sposób sformułowany wniosek taktyczny, z prośbą do Marszalka, by zaprosił Prezydenta RP do otwarcia osobiście sesji Sejmu ${ }^{78}$.

Większość uwag Rataja na temat Poniatowskiego jest bardzo krytyczna. W świetle jego "Pamiętników” Poniatowski był sejmowym enfant terrible ${ }^{79}$, wykorzystywał pełnioną funkcję wicemarszałka, nie potrafił sprostać roli posła. Czytając

${ }^{74}$ Ss. nr 254, 13 XI 1925, s. 80; AZHRE, A. Bogusławski, Wspomnienia, T. VI (V1926-1927), sygn. P-35, s. 511; A. Ajnenkiel, Parlamentaryzm II Rzeczypospolitej, Warszawa 1975, s. 222.

${ }^{75}$ Ss. nr 293, 17 VII 1926, s. 91.

${ }^{78}$ M. Rataj, op.cit., s. 406.

${ }^{77}$ Ss. nr 293, 17 VII 1926, s. 467; S. Jarecka-Kimlowska, Sylwester Wojewódzki, [w:] Przywódcy ruchu ludowego. Szkice biograficzne, pr. zbiot. pod red. A. Więzikowej, Warszawa 1968, s. 382-396.

${ }^{78}$ M. Rataj, op.cit., s. 424, 439.

${ }^{79}$ Ibidem, s. 406. 
wspomnienia Rataja trzeba jednak pamiętać, iż byl on dawnym kolegą klubowym Poniatowskiego, który odszedł z "Wyzwolenia” do "Piasta”. Miał w związku z tym krytyczny stosunek do całego ugrupowania, z którego się wywodził. Wbrew przytaczanym przez niego krytycznym ocenom wydaje się, że Poniatowski jako wicemarszałek w pracach sejmowych był obiektywny. W sprawozdaniach stenograficznych rzadko zdarzają się uwagi mogące świadczyć o tym, iż nie był w stanie utrzymać porządku na sali obrad. Zazwyczaj oddawal głos kolejnym posłom i prowadził głosowania nad ustawami, pilnując ustalonego porządku obrad, bez faworyzowania własnego ugrupowania i bez sprzeciwów zebranych na sali przedstawicieli klubów poselskich. Zdarzyła się nawet sytuacja, iż prowadził rozprawę nad budżetem Ministerstwa Wyznań Religijnych i Oświecenia Publicznego, w czasie której Józef Putek użył wyrażenia „sowiet" pod adresem "komitetu biskupów”. Gdy $z$ sali zwrócono Poniatowskiemu uwagę na ten fakt, 2 razy przywolal Putka do porządku - mimo, iż był to jego klubowy kolega ${ }^{80}$.

19 września 1927 r. J. Poniatowski zrzekł się mandatu, a 3 listopada 1927 roku złożył ślubowanie poseł Antoni Anusiak wybrany na jego miejsce ${ }^{81}$. Przyczynił się do tego $z$ pewnością fakt, iż Poniatowski czuł się związany z Piłsudskim, w związku z czym opowiadał się za umiarkowaną krytyką rządu, podczas gdy większość działaczy PSL, „Wyzwolenie” opowiedziała się za zaostrzeniem stosunku wobec rządu ${ }^{82} .31$ grudnia 1926 r. został wybrany wiceprezesem Prezydium Klubu Parlamentarnego PSL „Wyzwolenie" i „Jedność Ludowa", mimo iź wahał się już w tym czasie, czy nie odsunąc się od polityki ${ }^{83}$. Przez cały okres międzywojenny Poniatowski zabierał głos w wiążących dla partii sprawach na wiecach i na forum Sejmu oraz współtworzył jej linię programową.

Składając mandat Poniatowski zaznaczył, iż "nie odstępuje od służby idei ludowej”, jednak do PSL „Wyzwolenie” już nigdy nie wrócil. Po kilku latach pracy na stanowisku wizytatora Liceum Krzemienieckiego ponownie zajął się polityką, jednak po stronie sanacji, pełniąc w czterech kolejnych rządach w latach 1934-1939 funkcję ministra rolnictwa i reform rolnych.

Władysław Czapliński wśród 11 wybitnych parlamentarzystów okresu międzywojennego wymienił Poniatowskiego ${ }^{84}$. $Z$ pewnością Poniatowski byl w tym czasie jednym $z$ aktywniejszych i wybitniejszych polityków PSL "Wyzwolenie”, choć jego działalność parlamentarna nie była wolna od błędów. Bezkompromisowy w sądach politycznych, potrafil zrazić do siebie bardziej umiarkowanych posłów. Choć sam zachowywał się kulturalnie i honorowo, postrzegany był przez pryzmat ugrupowania, w którego szeregach zasiadał wspólnie $z$ działaczami nie przestrzegającymi zasad parlamentarnego dobrego wychowania. Wyważony jako poseł, sumienny i pracowity, skrupulatnie przygotowywał się do swych wystąpień

\footnotetext{
${ }^{80}$ Ss. nr 140, 1 VII 1924, s. 61.

${ }^{81}$ Ss. nr 338, 19 IX 1927, s. 3; S. Giza, op.cit., s. 93.

${ }^{82}$ S. Lato, Ewolucja PSL..., s. 185.

${ }^{83}$ S. Giza, op.cit., s. 83, 90.

${ }^{84}$ W. Czapliński, Dzieje sejmu polskiego do roku 1939, Kraków-Wrocław 1984, s. 106.
} 
sejmowych. Choć nie wszyscy zgadzali się z jego ideami i propozycjami poprawy: sytuacji bytowej drobnych właścicieli ziemskich, nie mogli mu zarzucić demago. gii. Zgłaszane projekty ustaw popierał rzeczową argumentacją.

Poniatowski starał się również zachowywać obiektywizm jako wicemarszałek, choć zdarzały mu się błędy. Zazwyczaj nie prowadził obrad, gdy tyczyły się one spraw rolnych. Być może wykorzystywał czasem znajomość regulaminu na po. trzeby swojej partii, jednak nigdy nie lamał jego zasad.

Pozytywnie wypada ocena Poniatowskiego jako polityka. Współtworzył program polityczny PSL „Wyzwolenie”, potrafil argumentować głoszone przez siebie poglądy i wytrwale dążył do ich realizacji. Nie raz Poniatowski dowodził swej samodzielności politycznej i nonkonformizmu, np. odmawiając pełnienia funkcji ministra. W 1927 roku, gdy PSL "Wyzwolenie” przeszło do opozycji względem Piłsudskiego, do którego Poniatowski żywił głęboki szacunek, honorowo odsunął się od polityki.

Czasem zarzucano mu jednak interesowność. Obok wspomnianego Rataja krytyczne uwagi pod adresem wypowiadał również Bogusławski, choć przyznawal, iż Poniatowski „był to człowiek inny od wielu kolegów sanatorów. Skrom ny osobiście, przejawiający duży poziom ideowy, choć o zabarwieniu przesadnie trochę doktrynerskim"ss. Bogusławski wspominał, iż Poniatowski był przeciwny połączeniu PSL „Wyzwolenie” z PSL „Piast”, bowiem obawiał się utraty stanowisk przez posłów swojej partii, nie zaś z powodu głębszej ideologii. Trudno dziś jednoznacznie stwierdzić, czy istotnie brak stanowisk był przyczyną, dla której Poniatowski sprzeciwiał się połączeniu z partią Witosa. Jeśli przyczyną była akcentowana przez „Wyzwolenie” współpraca „Piasta” z prawicą, niechęć do zacieśniania kontaktów z galicyjskimi ludowcami wydaje zrozumiała: wszak "Wyzwolenie" prezentowało poglądy lewicowe.

Działalności Poniatowskiego przyświecała idea - dążenie do poprawienia sytuacji drobnych właścicieli ziemskich. Fakt, iż Poniatowski wytrwale dążył do realizacji obranego celu mimo, iż wiązało się to czasem $z$ odrzucaniem intratnych stanowisk politycznych, przesądza o tym, iż Poniatowskiemu należy się miejsce wśród wybitnych parlamentarzystów okresu międzywojennego.

${ }^{85}$ AZHRL, A. Bogusławski, Wspomnienia, T. IX (1933-1935), sygn. P-38, s. 1150. 